\title{
Effects of prepartum controlled-energy wheat straw and grass hay diets supplemented with starch or sugar on periparturient dairy cow performance and lipid metabolism
}

\author{
N. B. Litherland, ${ }^{* 1}$ D. N. L. da Silva, ${ }^{*}$ W. P. Hansen, ${ }^{*}$ L. Davis, $†$ S. Emanuele, $\dagger$ and H. Blalock† \\ *Department of Animal Sciences, University of Minnesota, St. Paul 55108 \\ †Quality Liquid Feeds Inc., 3586 State Road 23 North, Dodgeville, WI 53533
}

\begin{abstract}
This study examined the effects of a forage source [wheat straw (WS) versus grass hay $(\mathrm{GH})]$ prepartum and supplemental carbohydrate source [corn (dry feed; DF) versus molasses (liquid feed; LF)] on pre- and postpartum intake, digestibility, selective particle consumption, milk yield, and lipid metabolism. The objectives were to determine if forage or pre- and postpartum supplement alters periparturient intake, energy balance, and milk yield. Sixty $(\mathrm{n}=15)$ multiparous dairy cows were used in a randomized complete block design with a $2 \times 2$ factorial arrangement of treatments to compare WS versus GH diets supplemented with either DF or LF. Dietary treatments were (1) WS prepartum + DF pre- and postpartum (WSDF), 2) WS prepartum + LF pre- and postpartum (WSLF), (3) GH prepartum + DF pre- and postpartum (GHDF), and (4) GH prepartum + LF pre- and postpartum (GHLF). Treatments began at dry-off, $42 \mathrm{~d}$ before expected calving. During the prepartum phase, cows maintained dry matter intake (DMI) at $2.0 \%$ of body weight and prepartum energy balance remained positive for all treatments until calving. Prepartum GH diets had a more positive energy balance compared with WS diets. On week -5 , energy balance was more positive for GHDF than for WSDF or GHLF. Energy balance for WSLF, however, was lower on week -3 and -1 than GHDF. Liquid feed decreased dry matter digestibility and increased prepartum liver triglyceride, serum nonesterified fatty acids (NEFA), and tended to increase $\beta$-hydroxybutyrate. After calving, LF decreased DMI and energy balance, but not yield of milk or $3.5 \%$ fat-corrected milk, resulting in greater feed efficiency compared with DF. Forage did not affect postpartum DMI, but milk yield tended to be higher for WS versus GH. The DMI expressed as percentage of body weight was not affected by supplement or prepartum forage type. Cows fed WS had lower
\end{abstract}

Received July 30, 2012.

Accepted January 27, 2013.

${ }^{1}$ Corresponding author: lithe003@umn.edu serum NEFA, higher liver glycogen, and tended to have a lower triglyceride to glycogen ratio postpartum than GH. Serum NEFA peaked on d 14 for all treatments and then declined thereafter. In postpartum diets, more particles were retained on the top screen for LF $(>19.0$ $\mathrm{mm}$ ) of the Penn State Particle Separator, which also tended to have more particles in the second screen (particles 19.0-8.0 mm). Supplement had minimal effect on postpartum selective particle consumption. In conclusion, feeding diets containing WS resulted in lower postpartum serum NEFA, higher liver glycogen, and a tendency for greater milk production and lower liver triglyceride to glycogen than those containing GH. Liquid feed reduced postpartum DMI but not yield of milk yield or $3.5 \%$ fat-corrected milk yield, resulting in an improvement in feed efficiency. Future research should continue to investigate the use of single dry cow diet feeding strategies as they affect pre- and postpartum animal responses.

Key words: transition cow, sugar, starch, forage

\section{INTRODUCTION}

Optimal dry cow feeding strategies to maintain DMI and energy balance (EB) during early lactation are not clearly defined. Additionally, few studies have focused on nutrition strategies during the entire peripartum period. High forage, controlled-energy diets received considerable research and on farm interest over the last 10 years (Beever, 2006; Dann et al., 2006; Janovick and Drackley, 2010). Controlled-energy feeding strategies offer marked advantages over feeding higher energy diets during the dry period, which is associated with a drop in prepartum DMI. Large relative changes in prepartum DMI have been linked to mobilization of adipose tissue, predisposing cows to metabolic disorders (Grummer et al., 2004; Janovick and Drackley, 2010).

High energy-density prepartum diets do not provide enough NDF to physically limit energy intake in multiparous cows (Vandehaar et al., 1999; Mashek and Beede, 2000; Agenäs et al., 2003; Rabelo et al., 2003). Additionally, dry cows fed high-forage diets $(70 \%$ of 
DM) ate less DM prepartum, but had a tendency to eat more DM postpartum than dry cows fed a low-forage, higher-energy TMR (Holcomb et al., 2001). However, previous research (Litherland et al., 2010) showed that dry cows fed diets containing $30 \%$ high-quality chopped orchard grass hay $(86 \% \mathrm{DM}$ as forage) produced more milk during the first week and had higher DMI during the first month postpartum than cows fed diets containing $30 \%$ chopped wheat straw $(60.7 \%$ DM as forage). Can similar changes in milk yield be achieved with lower quality grass hay that is more characteristic of that fed to dry cows?

Previous research (Dann et al., 2006; Litherland et al., 2010; Janovick et al., 2011) has evaluated the use of wheat straw in dry cow diets, but only limited published research has evaluated other low-energy forage sources. Grass hay, another forage option, provides more protein and energy relative to straw and is a high-NDF forage that is attractive for inclusion into dry cow diets. However, higher energy, protein content, and NDF digestibility (NDFd) relative to straw limit grass's role to dilute energy density of the diet.

The effect of dietary forage on prepartum DMI and selective particle consumption may be altered by source and form of supplemental carbohydrates. Few studies have explored supplemental sugar in the form of liquid feed for dry cows. Miller et al. (2005) replaced 3.2\% of corn grain in the far-off diet and $3.3 \%$ in the close-up diet with cane molasses and reported that molasses-fed cows tended to have higher DMI during the close-up period, ate 7\% more DM in the first month of lactation, and tended to have a higher milk yield. Similarly, Miller et al. (2007) fed cane molasses at 3.3\% of far-off diet, and $3.6 \%$ of close-up diet and reported cows receiving molasses during the dry period had higher DMI during the close-up period and tended to have greater postpartum DMI and greater milk production. Maintaining DMI before calving with supplemental liquid molasses would prevent decreases in energy intake resulting in improved periparturient performance. Sucrose and cane molasses supplementation to lactating cows increased DMI (Broderick and Radloff, 2004; Firkins et al., 2008; Broderick et al., 2008; Penner and Oba, 2009). However, DMI response to sugar supplementation has been variable and is likely dependent on the nitrogen source (Firkins et al., 2008) and the amount of diet forage amount and quality (Broderick and Radloff, 2004). Nombekela and Murphy (1995) supplemented 1.5\% sucrose and noted a transient increase in DMI for the first 2 wk postpartum compared with control, and less variation in $3.5 \% \mathrm{FCM}$ production for the first $12 \mathrm{wk}$ of lactation.

Selective consumption by cows against low energydensity forage particles and selective consumption of higher energy dense particles would result in greater energy intake than intended for a diet as formulated. Dry cows are effective sorters against long particles, and for short and fine particles when fed a corn silagebased diet containing 39.5\% alfalfa hay (Hosseinkhani et al., 2008). Using a cane molasses-based liquid feed within a dry cow TMR may offer a novel approach to deliver nutrients and reduce sorting. Effects of liquid feeds on particle distribution and selective consumption of particles by dry cows has not yet been explored in a research setting. Research is needed to explore ingredient combinations for dry cow diets that optimize periparturient DMI without excessive energy intake and prepare cows for a successful transition into lactation.

The objectives of this study were to compare a cornbased dry feed (DF) supplement versus a molassesbased liquid feed (LF) supplement in dry cow TMR containing either $30 \%$ chopped wheat straw (WS) or $30 \%$ chopped grass hay (GH). Our hypothesis was that dietary supplementation with LF would result in greater periparturient DMI than DF, and that prepartum diets containing GH would result in greater periparturient DMI than WS. Additionally, we hypothesized that molasses-based LF would reduce diet sorting and improve the consistency of pre-and postpartum nutrient and energy intake compared with DF.

\section{MATERIALS AND METHODS}

\section{Cows and Treatments}

This experiment was conducted from September 2009 to April 2010 at the University of Minnesota Dairy Teaching and Research Center. The Institutional Animal Care and Use Committee of the University of Minnesota approved the experimental protocol (ACUP \# 0907A70341). Sixty multiparous Holstein and Holsteincross $($ Holstein $\times$ Montbéliarde $\times$ Swedish Red) dairy cows were assigned to 1 of 4 dietary treatments $45 \mathrm{~d}$ before their projected calving date and were removed from the study at 56 DIM. Treatments were balanced at the start of the experiment for breed, lactation number (mean $\pm \mathrm{SEM}=3.0 \pm 0.3$ ), previous lactation 305-d mature equivalent for milk production $(11,253 \pm 320.8$ $\mathrm{kg})$, and BCS at dry-off (3.51 \pm 0.11 ; Table 1). As planned, the number of days on dietary treatments did not differ among groups, as cows were dry for $41 \pm 2.0$ d (Table 1). Cows were housed in individual tiestalls with rubber-filled mattresses and bedded with sawdust in a mechanically ventilated barn. Cows were moved to a calving area once calving appeared imminent and were returned to their tiestalls after calving. Cows were fed once daily during the dry period $(1200 \mathrm{~h})$ and twice daily after calving (0400 and 1100 h). After calving, 
Table 1. Description of multiparous dairy cows fed wheat straw or grass hay diets prepartum with either starch or sugar supplement both pre- and postpartum

\begin{tabular}{lccccc}
\hline & \multicolumn{5}{c}{ Diet $^{1}$} \\
\cline { 2 - 4 } Variable & WSDF & WSLF & GHDF & GHLF & SEM \\
\hline No. & 15 & 15 & 15 & 15 & - \\
305-d Mature-equivalent milk yield, & 11,329 & 11,322 & 11,218 & 11,142 & 707 \\
previous lactation, kg & & & & & \\
BCS d (-42) & 3.45 & 3.63 & 3.38 & 3.58 & 0.11 \\
Parity & 2.9 & 3.3 & 2.9 & 3.0 & 0.28 \\
Days dry & 41.1 & 37.9 & 43.1 & 41.9 & 2.0 \\
\hline
\end{tabular}

${ }^{1}$ Diets fed from d 42 prepartum through d 56 postpartum; wheat straw prepartum + corn-based dry feed pre- and postpartum (WSDF); wheat straw prepartum + molasses-based liquid feed pre- and postpartum (WSLF); grass hay prepartum + dry feed pre- and postpartum (GHDF); GH prepartum + liquid feed pre- and postpartum (GHLF).

cows were milked twice daily (0100 and $1300 \mathrm{~h})$. Two cows were removed from the study (not pregnant and leg injury) and replaced with equivalent cows, resulting in 60 cows completing the study.

Dry feed and LF were designed to vary only in carbohydrate source, and used similar macro- and micro-mineral ingredients and supplemental amounts to provide a TMR with equal mineral and vitamin composition (Table 2). The LF contained cane molasses, condensed whey, urea, and calcium carbonate. The DF contained ground corn $(62.4 \%)$, calcium carbonate $(8.5 \%)$, and urea $(8.2 \%)$. Complete ingredient listing for both supplements is in the footnote of Table 2. Both mixes were fed at $6.3 \%$ of diet DM; LF was stored in a poly tank complete with recirculation pump and DF was stored in $25-\mathrm{kg}$ paper bags. The LF was added to diets using an overhead manifold after the recirculating pump was allowed to run for $10 \mathrm{~min}$ before each feeding. Both LF and DF were the last ingredient added to the TMR.

Prepartum treatments (Tables 3 and 4) included (1) WS prepartum + DF pre- and postpartum (WSDF), (2) WS prepartum + LF pre- and postpartum (WSLF), (3) GH prepartum + DF pre- and postpartum (GHDF), and (4) GH prepartum + LF pre- and postpartum (GHLF). Postpartum treatments were a common lactation diet supplemented with LF or DF to produce 2 dietary treatments (Table 4). Diets were formulated using the Cornell-Penn-Miner System (CPM Dairy, version 3.0.8; Cornell University, Ithaca, NY; University of Pennsylvania, Kennett Square, PA; and William H. Miner Agricultural Research Institute, Chazy, NY) to supply adequate $\mathrm{NE}_{\mathrm{L}}$ and $\mathrm{MP}$ for a 650 $\mathrm{kg}$ dry cow at $280 \mathrm{~d}$ in gestation prepartum and a 650 $\mathrm{kg}$ cow producing $40 \mathrm{~kg}$ of milk with a fat concentration of $3.5 \%$ postpartum. Diets (Tables 2 and 3 ) were fed at an ad libitum rate (to ensure $10 \%$ feed refusals) and were formulated to be isocaloric, isonitrogenous, and provide an equal amount of forage NDF by varying the amount of corn silage, dry corn, and soybean meal in the diet. Prepartum diets were formulated to provide $30 \%$ chopped WS or GH. Wheat straw and GH were chopped in a vertical mixer for $40 \mathrm{~min}$ to reduce particle size to a uniform consistency between forages. Supplemental LF amount was selected to be representative of amounts fed in the field without exceeding $8 \%$ total dietary sugar. Tap water was added to WSDF to maintain equal DM among TMR treatments. Individual ingredient DM\% was adjusted weekly to maintain the correct proportions of feeds on a DM basis in the offered diets. The DM\% was determined by drying in a $100^{\circ} \mathrm{C}$ oven and adjusting ingredient amount fed.

Individual ingredients were sampled weekly, frozen at $-20^{\circ} \mathrm{C}$ and composited monthly on a wet weight basis, dried in a $60^{\circ} \mathrm{C}$ forced air oven for $48 \mathrm{~h}$ (or until static weight was achieved) and then ground through a 1-mm screen in a Wiley mill (Thomas-Wiley, Philadelphia, PA). Dried ground samples were analyzed at Dairyland Laboratories (St. Cloud, MN) using wet chemistry methods. Monthly averages of the nutrient composition of individual ingredients were used in the CPM Dairy model to calculate the nutrient composition of the diets. Organic matter concentration of feed and feces was calculated as the difference between DM content and ash content. Ash content was determined using method 942.05 (AOAC International, 2000). Crude protein was determined using method 990.03 (AOAC International, 2000). Heat-stable, $\alpha$-amylasetreated, sodium sulfite NDF for feed ingredients and fecal samples was determined using an Ankom 200 fiber analyzer (Ankom Technology, Macedon, NY) based on procedures described by VanSoest et al. (1991). Acid detergent fiber was determined using method 973.18 (AOAC International, 2000). Lignin was determined using method 973.18. Levels of ADF-insoluble CP was determined by method 973.18 (AOAC International, 2000) and ether extract was determined by method 920.39 (AOAC International, 2000). Concentrations 
Table 2. Chemical composition of dry feed (DF) and liquid feed (LF) supplements and wheat straw (WS) and grass hay $(\mathrm{GH})$

\begin{tabular}{lcccc}
\hline & \multicolumn{3}{c}{ Ingredient } \\
\cline { 2 - 4 } Item & $\mathrm{DF}^{1}$ & $\mathrm{LF}^{2}$ & $\mathrm{WS}$ & $\mathrm{GH}$ \\
\hline Chemical, \% DM & & & & \\
DM & 95.5 & 63.0 & 93.1 & 87.5 \\
CP & 29.2 & 31.7 & 2.4 & 14.4 \\
ADF & 2.2 & - & 53.6 & 29.6 \\
NDF & 6.0 & - & 75.0 & 58.6 \\
Lignin & 2.4 & - & 8.9 & 3.9 \\
Starch & 40.3 & 0.0 & 0.4 & 0.7 \\
TSAI & 2.3 & 39.7 & 1.9 & 5.9 \\
Ether extract & 1.1 & 0.0 & 1.2 & 2.7 \\
Ash & 26.6 & 26.3 & 1.2 & 1.6 \\
Calcium & 4.5 & 5.9 & 0.2 & 0.4 \\
Phosphorous & 0.3 & 0.7 & 0.08 & 0.4 \\
Magnesium & 0.9 & 1.1 & 0.1 & 0.3 \\
Potassium & 3.3 & 3.5 & 1.6 & 3.1 \\
Sulfur & 2.5 & 2.1 & 0.1 & 0.2 \\
Sodium & 0.16 & 0.29 & 0.02 & 0.02 \\
Chlorine & 0.27 & 2.38 & 0.42 & 0.32 \\
Particles retained, \% as fed & & & & \\
$>19.0$ mm & & & 6.1 & 27.1 \\
19.0 to 8.0 mm & & & 51.2 & 35.7 \\
8.0 to 1.18 mm & & & 35.1 & 27.6 \\
$<1.18$ mm & & & 7.6 & 9.6 \\
\hline
\end{tabular}

${ }^{1} \mathrm{DF}$ prepared by Munson Lakes Nutrition, Howard Lake, MN. Ingredients: corn grain, calcium carbonate, urea, calcium sulfate, potassium chloride, magnesium sulfate, mono-dicalcium phosphate, magnesium oxide, dairy trace mineral premix, selenium, vitamin E supplement, ferrous sulfate, ethylenediamine dihydriodide.

${ }^{2}$ LF prepared by Quality Liquid Feeds, Dodgeville, WI. Ingredients: cane molasses, condensed whey, calcium carbonate, urea, ammonium sulfate, magnesium sulfate, ammonium polyphosphate, magnesium oxide, vitamin E supplement, zinc sulfate, manganese sulfate, xanthan gum, copper sulfate, sodium selenite, vitamin A supplement, ethylenediamine dihydriodide, ferrous sulfate, cobalt sulfate and vitamin $\mathrm{D}_{3}$ supplement.

${ }^{3}$ Total sugar as invert.

of minerals in feed were determined by method 985.01 (AOAC International, 2000). Total sugar (expressed as invert) was determined by method 968.28 (AOAC International, 2000). Starch was determined using an enzymatic method described by Bach Knudsen (1997).

\section{Nutrient Intake}

Individual cow DMI was measured daily from dry-off to 56 DIM. Feed offered and refused were measured daily and recorded electronically. The DMI was calculated by correcting as-fed offered minus refusals and multiplied by weekly diet DM for each treatment. Energy balance both pre- and postpartum was calculated for each cow using equations described by (NRC, 2001). Net energy intake was determined by multiplying DMI by the calculated mean $\mathrm{NE}_{\mathrm{L}}$ density of the diet. The $\mathrm{NE}_{\mathrm{L}} 3 \times$ maintenance was predicted from total digestible nutrients according to the NRC (2001). The $\mathrm{NE}_{\mathrm{L}}$ value for forages was adjusted with the Van Soest variable discount method (Dairy One, 1999). Weekly means for individual cows were used as model inputs for prepartum DMI, and BW were used for prepartum
EB calculations. Postpartum EB was calculated using inputs of weekly averages of DMI, BW, milk yield, and milk composition. Intake of $\mathrm{CP}$, ethanol-soluble carbohydrates, starch, OM, NDF, and ADF were calculated based on mean weekly intake for each cow and diet composition for each treatment.

\section{$B W$ and $B C S$}

Body weight was measured and BCS was assigned on 0.25-unit increments (Ferguson et al., 1994) for each cow weekly from dry-off to 56 DIM. Three individual scorers assigned BCS weekly and averages of the 3 scores are reported.

\section{Apparent Total-Tract Digestibility}

To estimate total-tract DM digestibility and OM digestibility during the dry period from $d-21$ to $d$ -14 , TMR and feed refusal samples were collected once daily for 1 wk and a total of 9 fecal grab samples per cow at 5 - to 8 -h intervals over a 72 -h period. The TMR and feed refusals were composited by treatment and 
Table 3. Ingredient composition for prepartum and postpartum diets fed as wheat straw or grass hay diets prepartum with either dry feed (DF) with starch or liquid feed (LF) with sugar supplement to multiparous dairy cows from $42 \mathrm{~d}$ prepartum through $56 \mathrm{~d}$ postpartum

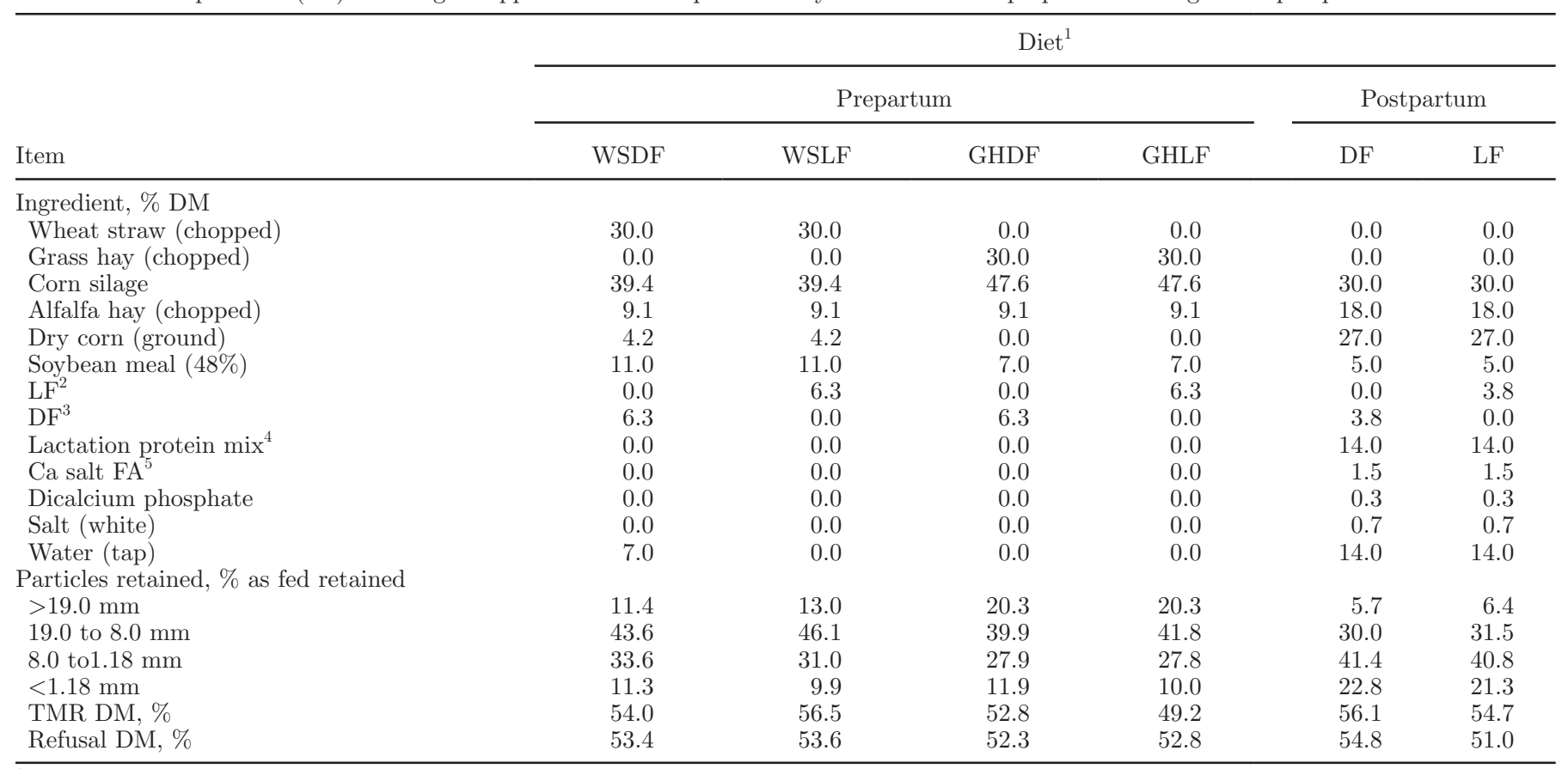

${ }^{1}$ Diets fed from $42 \mathrm{~d}$ prepartum through $56 \mathrm{~d}$ postpartum; wheat straw prepartum + corn-based DF pre- and postpartum (WSDF); wheat straw prepartum + molasses-based LF pre- and postpartum (WSLF); grass hay prepartum + DF pre- and postpartum (GHDF); GH prepartum + LF pre- and postpartum (GHLF); lactation TMR with DF (Starch); lactation TMR with LF (Sugar).

${ }^{2}$ Molasses-based LF (Quality Liquid Feeds, Dodgeville, WI).

${ }^{3}$ Dry corn-based custom grain mix (Munson Lake Nutrition, Howard Lake, MN).

${ }^{4}$ Composition: $29.8 \%$ CP, $19.2 \%$ ADF, $34.8 \%$ NDF, $15.7 \%$ ash, $7.2 \%$ ether extract, $1.3 \%$ Ca, $0.9 \%$ P, $0.4 \%$ Mg, $2.2 \%$ K, $0.39 \%$ S, $1.7 \%$ Na, $0.8 \%$ $\mathrm{Cl}$.

${ }^{5}$ Megalac (Church and Dwight, Princeton, NJ).

fecal samples were composited by cow on a wet weight basis, dried at $60^{\circ} \mathrm{C}$ to a constant weight and ground through a $1-\mathrm{mm}$ screen in a Wiley mill. Analysis of TMR, feed refusals, and fecal samples included DM, $\mathrm{OM}$, and NDF digestibility using acid-insoluble ash as an internal marker as described by Block et al. (1981).

\section{Milk Yield and Composition}

Milk weights were recorded from 1 to 56 DIM and samples were obtained from consecutive a.m. and p.m. milkings weekly from 8 to 56 DIM. Milk samples were preserved (800 Broad Spectrum Microtabs II; D and F Control Systems Inc., San Ramon, CA) and were analyzed for fat, protein, lactose, urea N, and SCC using mid-infrared procedures (method 972.16; AOAC International, 2000) at a commercial laboratory (DHIA, Zumbrota, MN).

\section{Concentrations of Serum NEFA and BHBA}

Blood was sampled from the coccygeal vein or artery on $\mathrm{d}-28,-14$, and -7 relative to expected parturition and at $\mathrm{d} 1,7,14$, and 28 relative to actual parturition. Samples were collected before feeding $(0800 \mathrm{~h})$ into evacuated serum tubes (Becton Dickinson Vacutainer Systems, Franklin Lakes, NJ) containing clot activator. Serum was obtained by centrifugation for $20 \mathrm{~min}$ at $1,300 \times g$. Aliquots of serum were frozen at $-20^{\circ} \mathrm{C}$ until later analysis for contents of NEFA (2Hr NEFA kit; Wako Chemicals USA Inc., Richmond VA) and BHBA (Precision Xtra; Abbott Laboratories Inc., North Chicago, IL).

\section{Liver Composition}

Liver was sampled via puncture biopsy (Hughes, 1962; Veenhuizen et al., 1991) from cows under local anesthesia at approximately $0700 \mathrm{~h}$ on $\mathrm{d}-14$ (to determine effects of dry period diets), 7 (to determine effect of dry period nutrition on the immediate lipid accumulation following parturition), 14, and 28. Liver was frozen immediately in liquid $\mathrm{N}$, transferred to a $-80^{\circ} \mathrm{C}$ freezer, and later analyzed for contents of total lipids (Hara and Radin, 1978), triacylglycerol (Fletcher, 1968; Foster and Dunn, 1973), and glycogen (Lo et al., 1970). 
Table 4. Nutrient composition of diets fed pre- and postpartum

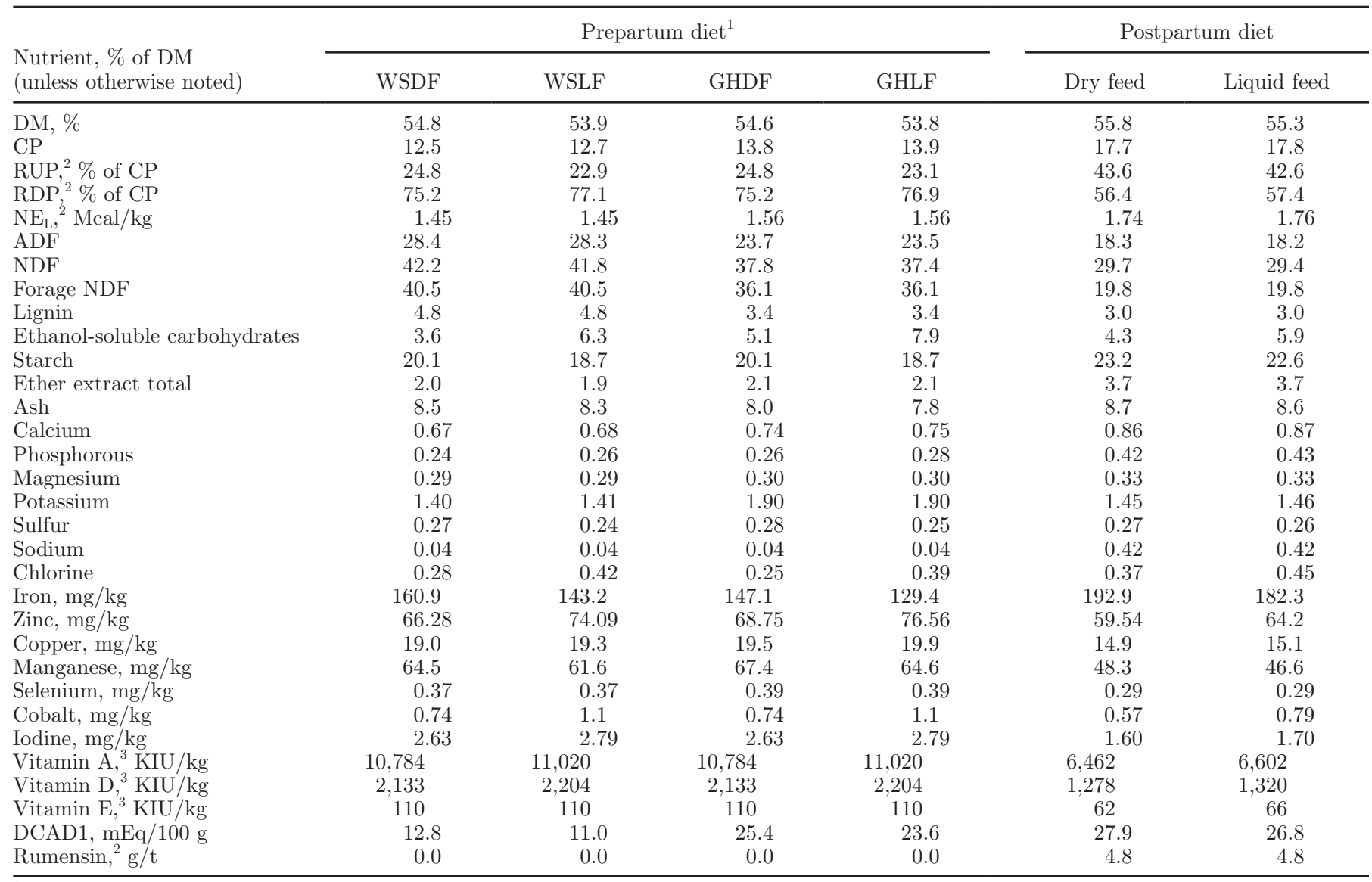

${ }^{1}$ Diets fed from $42 \mathrm{~d}$ prepartum through $56 \mathrm{~d}$ postpartum; wheat straw prepartum + corn-based dry feed pre- and postpartum (WSDF); wheat straw prepartum + molasses-based liquid feed pre- and postpartum (WSLF); grass hay prepartum + dry feed pre- and postpartum (GHDF); GH prepartum + liquid feed pre- and postpartum (GHLF); lactation TMR with dry feed (Starch); lactation TMR with liquid feed (Sugar).

${ }^{2}$ Values estimated using Cornell-Penn-Miner System (CPM Dairy, version 3.0.8; Cornell University, Ithaca, NY; University of Pennsylvania, Kennett Square, PA; and William H. Miner Agricultural Research Institute, Chazy, NY).

${ }^{3}$ Formulated amount.

\section{Diet Sorting Analysis}

Samples of TMR and orts were collected from each cow on $\mathrm{d}-21$ to -19 and 19 to 21 from individual feed bunks and composited into 1 prepartum and 1 postpartum sample for each cow. Particle size distribution was determined by shaking in a Penn State Particle Separator (PSPS) and particles from each screen were dried at $60^{\circ} \mathrm{C}$ for $48 \mathrm{~h}$. Intake of particles on an as-fed basis was calculated for each screen for each cow as the difference between diets offered and refused. Sorting was calculated by the product of kilograms as-fed intake, percent DM of each screen, and the percentage of the fraction of each screen, and then all values were divided as the product of kilograms as-fed offered, percent DM of each screen, and the percentage of the fraction of that respective screen. Selective particle consumption was defined using guidelines described by Leonardi et al. (2005); values equal to $100 \%$ represent no sorting,
$<100 \%$ show selective refusals, and $>100 \%$ indicate preferential consumption.

\section{Statistical Analysis}

Statistical computations were performed using SAS (Release 9.2: SAS Institute Inc., Cary, NC). The data were analyzed as a randomized complete block design with a $2 \times 2$ factorial arrangement of treatments using the MIXED models procedure of SAS (Littell et al., 1996). Prepartum and postpartum data were analyzed separately. Model included the effects of forage, supplement, week and breed. Data measured over time were analyzed as repeated measures with 3 covariance structures: compound symmetry, auto-regressive order 1 and unstructured covariance. The covariance structure that resulted in the Akaike information criterion closest to zero was used (Littell et al., 1996). Least squares means for treatment effects were separated by use of 
the PDIFF statement when the overall F-test was $P \leq$ 0.05 . Trends are indicated when $P \leq 0.10$.

\section{RESULTS AND DISCUSSION}

\section{Prepartum DM and Nutrient Intake}

No effects of forage or supplement on prepartum DMI were observed (Table 5). A forage $\times$ supplement $\times$ week interaction occurred at the start of the dry period. On wk -5 , DMI was higher for GHDF than WSDF and DMI was higher for GHDF than GHLF. Prepartum DMI for WSLF was lower than GHDF on wk -3 and -1 , however. As a percentage of BW, DMI was not affected by prepartum forage or supplement and averaged $2.0 \pm 0.1 \%$ (Table 5). Prepartum DMI expressed as a percentage of BW did not decrease as calving approached. An interaction of forage $\times$ week occurred on wk -4 and -3 , as GH had higher DMI as a percentage of BW than WS. Previous research with cane molasses fed at $3.3 \%$ of far-off and $3.6 \%$ of close-up dry cow diets resulted in increased DMI during the close-up period (Miller et al., 2007). Prepartum intake of $\mathrm{NE}_{\mathrm{L}}$ was higher $(P=0.05)$ for $\mathrm{GH}$ compared with WS. Prepartum EB tended $(P=0.06)$ to be lower for WS versus GH, but was unaffected by supplement. Prepartum EB expressed as a percentage of requirements indicated cows fed WS tended $(P=0.08)$ to be in less positive $\mathrm{EB}(137.1 \%)$ than cows fed GH (155.6 \pm $11.3 \%$ ). Moderating energy intake is one of the primary goals of moderate-energy, high-NDF prepartum diets. Previous research has shown that excessive positive prepartum EB resulted in cows with more negative EB during the first 10 DIM, although over the first 8 wk of lactation these effects dissipated (Dann et al., 2006). Additionally, cows overfed energy prepartum took much longer to reach positive EB postpartum and had a larger EB deficit during the first $4 \mathrm{wk}$ and 8 wk of lactation (Agenäs et al., 2003). In the present study, calculated prepartum starch intake was higher $(P<0.02)$ for DF compared with LF supplemented cows. Additionally, calculated ESC intake was higher $(P<0.001)$ for LF versus DF, and ESC intake was also higher $(P<0.001)$ for GH versus WS. Calculated $\mathrm{CP}$ intake was higher $(P=0.01)$ for GH versus WS. Prepartum OM and NDF intake were similar among treatments. Intake of $\mathrm{ADF}$ tended $(P=0.08)$ to be higher for WS versus GH.

\section{Prepartum Apparent Total-Tract Nutrient Digestibility, BW, and Body Condition}

Amounts of DMI on wk -3 during the sampling period for diet digestibility were similar among treatments
(Table 5). Fecal DM percent was higher $(P<0.008)$ for LF versus DF, but was unaffected by forage source. Prepartum digestibility of $\mathrm{DM}$ and $\mathrm{OM}$ and amount of DM digested and OM digested was not affected by forage source but was greater $(P<0.03)$; OM digested tended $(P=0.08)$ to be greater for DF compared with LF. Surprisingly, NDFd was higher $(P<0.02)$ for WS versus $\mathrm{GH}$; this could be due to the combination of numerically lower DMI for WS versus GH, longer ruminal retention time, greater sorting against long particles in the WS diets, and $4.4 \%$ lower NDF concentration in GH diets. Similar to results from this study, Colucci et al. (1982) varied NDF content in diets fed to dry cows and observed a decrease in NDFd similar to that observed in this study. The amount of NDFd tended ( $P$ $=0.06)$ to be lower for LF versus DF. Prepartum BW was not different among treatments and increased $(P<$ $0.05)$ as parturition approached; however, LF increased $(P<0.04)$ BCS compared with DF, but the increase of 0.1 to $0.2 \mathrm{BCS}$ is not likely biologically significant. Prepartum BW gain during the dry period was greater $(P<0.05)$ for cows fed DF versus LF, but forage type did not have an effect. Additionally, prepartum BCS change followed a similar trend, as BW change with cows fed DF adding more $(P<0.05)$ BCS than LF and cows fed GH gaining less $(P<0.05)$ BCS than WS (Table 5).

\section{Postpartum DMI, EB, BW, and Body Condition}

Postpartum DMI was not affected by forage source but was higher $(P<0.008)$ for DF versus $\mathrm{LF}$, however, DMI as a percentage of BW was not different between forages $(P=0.33)$ or supplements $(P=0.26$; Table 6$)$. An increase in DMI $(P<0.001)$ with increasing DIM was noted. Previous work with sugar supplementation in lactating cows has often shown an increase in DMI (Broderick and Radloff, 2004; Broderick et al. 2008; Firkins et al., 2008; Penner and Oba, 2009). Postpartum DMI and DMI as a percentage of BW for this trial were comparable to those observed in previous studies feeding moderate-energy, high-forage (MEHF) diets prepartum (Dann et al., 2006; Janovick and Drackley, 2010). Penner and Oba (2009) fed low- (4.7\%) or high-sugar $(8.4 \%)$ diets to dairy cows after calving and reported a 1.1-kg increase in DMI for cows fed the high-sugar diet. Results from the present study and that by Penner and Oba (2009) are not directly comparable because of differences in the amount of sugar supplemented and differences in nutrient composition of the diets. Previous research (Rérat et al., 2009) demonstrated that varying the concentration of potassium in grass hay fed prepartum had an effect on postpartum DMI. Cows fed grass hay with a potassium concentration of $13 \mathrm{~g} / \mathrm{kg}$ 
Table 5. Prepartum (wk -6 to calving) DMI, DMI expressed as a percentage of BW, energy balance, nutrient intake and digestibility, and BW and BCS for multiparous dairy cows fed wheat straw (WS) or grass hay (GH) diets prepartum with either a dry feed (DF) with starch or a liquid feed (LF) with sugar supplement both pre- and postpartum

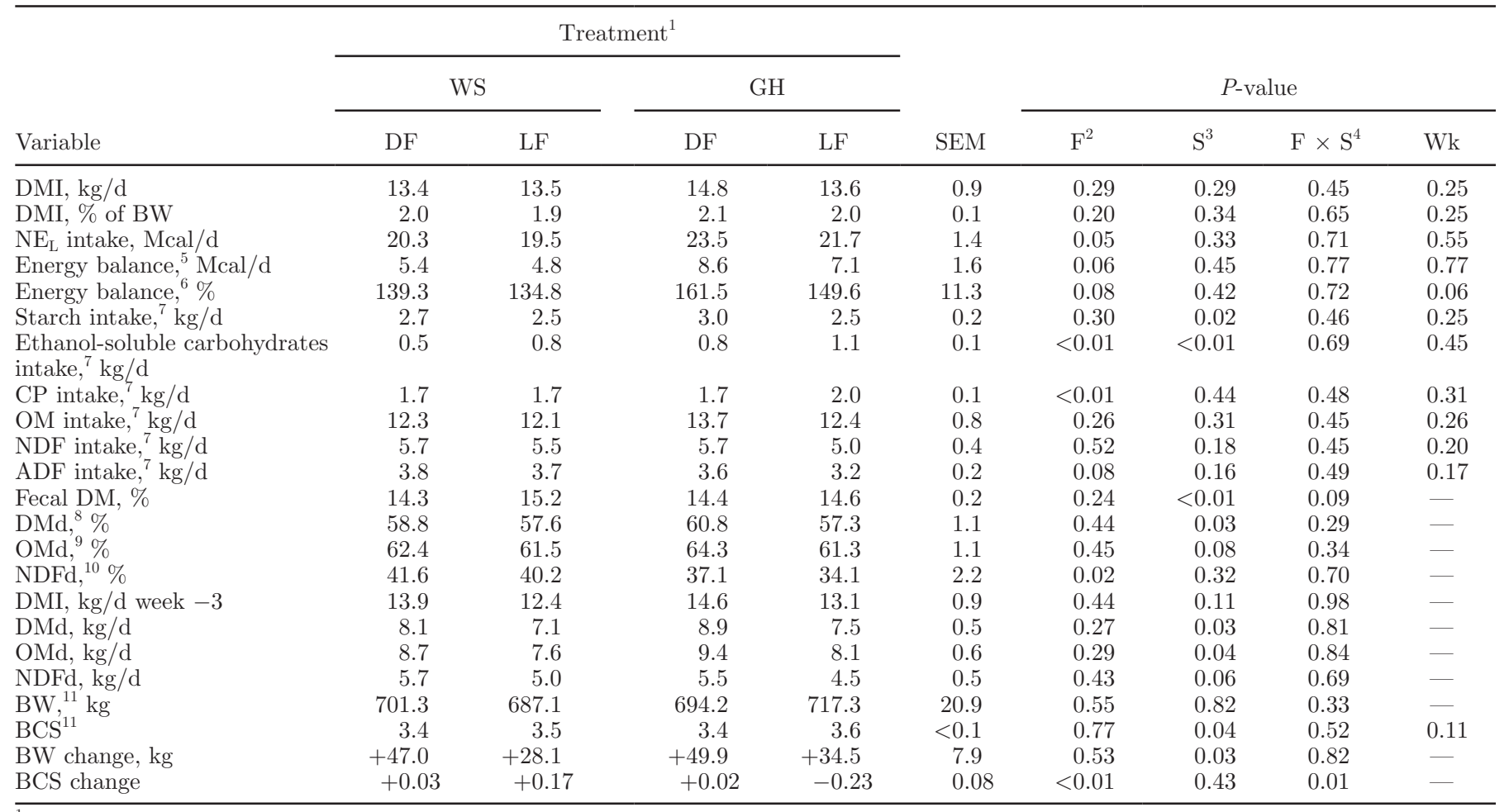

${ }^{1}$ Diets fed from $42 \mathrm{~d}$ prepartum through $56 \mathrm{~d}$ postpartum; wheat straw prepartum + corn-based DF pre- and postpartum (WSDF); wheat straw prepartum + molasses-based LF pre- and postpartum (WSLF); grass hay prepartum + DF pre- and postpartum (GHDF); GH prepartum + LF pre- and postpartum (GHLF); lactation TMR with DF (Starch); lactation TMR with LF (Sugar).

${ }^{2}$ Wheat straw vs. grass hay diets.

${ }^{3}$ Starch vs. sugar supplement.

${ }^{4}$ Interaction of forage type and supplement type.

${ }^{5}$ Energy balance $=\mathrm{NE}_{\mathrm{I}}-\left(\mathrm{NE}_{\mathrm{M}}+\mathrm{NE}_{\mathrm{P}}\right)$, where $\mathrm{NE}_{\mathrm{I}}=$ net energy intake and $\mathrm{NE}_{\mathrm{P}}=$ net energy for pregnancy.

${ }^{6}$ Percentage of $\mathrm{NE}_{\mathrm{L}}$ requirement.

${ }^{7}$ Average daily prepartum nutrient intake.

${ }^{8}$ Apparent total-tract digestibility of DM. Feed and fecal samples were collected from wk -3 to -2 relative to expected calving date to determine digestibility using acid insoluble ash as an internal maker.

${ }^{9}$ Apparent total-tract digestibility of OM. Feed and fecal samples were collected from wk -3 to -2 relative to expected calving date to determine digestibility using acid insoluble ash as an internal maker.

${ }^{10}$ Apparent total-tract digestibility of NDF. Feed and fecal samples were collected from wk -3 to -2 relative to expected calving date to determine digestibility using acid insoluble ash as an internal maker.

${ }^{11}$ Measurements collected weekly.

had greater DMI during the first week of lactation than cows fed grass hay with a potassium concentration of $33 \mathrm{~g} / \mathrm{kg}$ (Rérat et al., 2009). Results from that study indicated that decreasing the DCAD by 228 versus 544 $\mathrm{mEq} / \mathrm{kg}$ of DM by feeding a low-potassium hay prepartum provided positive benefits in mineral balance in the first week postpartum. Prepartum diets in the present study delivered 188 and $270 \mathrm{~g} / \mathrm{d}$ of K for WS and GH diets, respectively. Perhaps increased dietary potassium from GH in this study was high enough to reduce feed intake during the first week postpartum, but this decrease was not large enough to be significant.
Due to higher DMI, calculated $\mathrm{NE}_{\mathrm{L}}$ intake and postpartum EB was higher $(P<0.01)$ for DF versus LF. Postpartum EB decreased until 3 wk postpartum, increased through wk 6 , but remained negative through 56 DIM. Energy balance expressed as a percentage of requirements averaged $90.0 \%$ for DF versus $79.8 \pm$ $4.2 \%$ for LF during the postpartum period (Table 6). Previous work demonstrated that EB was not different between control and sucrose-supplemented cows; however, energy intake was greater and energy output tended to be higher in sucrose-supplemented cows (Penner and Oba, 2009). As designed, calculated starch 
Table 6. Postpartum DMI, DMI as a percentage of BW, nutrient intake, and BW and BW change for multiparous dairy cows fed wheat straw (WS) or grass hay $(\mathrm{GH})$ diets prepartum with either a dry feed (DF) with starch or a liquid feed (LF) with sugar supplement both pre- and postpartum

\begin{tabular}{|c|c|c|c|c|c|c|c|c|c|}
\hline \multirow[b]{2}{*}{ Variable } & \multicolumn{4}{|c|}{ Treatment $^{1}$} & \multirow[b]{2}{*}{ SEM } & \multicolumn{4}{|c|}{$P$-value } \\
\hline & DF & $\mathrm{LF}$ & $\mathrm{DF}$ & LF & & $\mathrm{F}^{2}$ & $\mathrm{~S}^{3}$ & $\mathrm{~F} \times \mathrm{S}^{4}$ & Wk \\
\hline DMI, kg/d & 21.3 & 17.7 & 20.9 & 19.3 & 1.0 & 0.53 & $<0.01$ & 0.54 & $<0.01$ \\
\hline DMI, $\%$ of BW & 3.2 & 3.1 & 3.4 & 3.2 & 0.1 & 0.33 & 0.26 & 0.65 & $<0.01$ \\
\hline $\mathrm{NE}_{\mathrm{L}}$ intake, Mcal/d & 37.1 & 31.2 & 36.4 & 32.8 & 1.9 & 0.80 & 0.01 & 0.43 & $<0.01$ \\
\hline Starch intake ${ }^{7} \mathrm{~kg} / \mathrm{d}$ & 4.8 & 4.2 & 4.8 & 4.4 & 0.2 & 0.50 & 0.01 & 0.60 & $<0.01$ \\
\hline $\begin{array}{l}\text { Ethanol-soluble } \\
\text { carbohydratesintake, }{ }^{7} \mathrm{~kg} / \mathrm{d}\end{array}$ & 0.9 & 1.1 & 0.9 & 1.1 & 0.1 & 0.37 & $<0.01$ & 0.56 & $<0.01$ \\
\hline $\mathrm{CP}$ intake ${ }^{7} \mathrm{~kg} / \mathrm{d}$ & 3.6 & 3.3 & 3.7 & 3.5 & 0.2 & 0.47 & 0.05 & 0.67 & $<0.01$ \\
\hline OM intake, ${ }^{7} \mathrm{~kg} / \mathrm{d}$ & 18.7 & 17.0 & 19.0 & 17.9 & 0.8 & 0.47 & 0.04 & 0.65 & $<0.01$ \\
\hline NDF intake,${ }^{7} \mathrm{~kg} / \mathrm{d}$ & 6.1 & 5.5 & 6.2 & 5.8 & 0.3 & 0.48 & 0.03 & 0.63 & $<0.01$ \\
\hline ADF intake, ${ }^{7} \mathrm{~kg} / \mathrm{d}$ & 3.8 & 3.4 & 3.8 & 3.6 & 0.2 & 0.50 & 0.03 & 0.63 & $<0.01$ \\
\hline
\end{tabular}

${ }^{1}$ Diets fed from $42 \mathrm{~d}$ prepartum through $56 \mathrm{~d}$ postpartum; wheat straw prepartum + corn-based DF pre- and postpartum (WSDF); wheat straw prepartum + molasses-based LF pre- and postpartum (WSLF); grass hay prepartum + DF pre- and postpartum (GHDF); GH prepartum + LF pre- and postpartum (GHLF); lactation TMR with DF (Starch); lactation TMR with LF (Sugar).

${ }^{2}$ Wheat straw vs. grass hay diets.

${ }^{3}$ Starch vs. sugar supplement.

${ }^{4}$ Interaction of forage type and supplement type.

${ }^{5}$ Energy balance $=\mathrm{NE}_{\mathrm{I}}-\left(\mathrm{NE}_{\mathrm{M}}+\mathrm{NE}_{\mathrm{L}}\right)$, where $\mathrm{NE}_{\mathrm{I}}=$ net energy intake.

${ }^{6}$ Percentage of $\mathrm{NE}_{\mathrm{L}}$ requirement.

${ }^{7}$ Average daily prepartum nutrient intake.

${ }^{8} \mathrm{Wk} 6$ BW minus wk $1 \mathrm{BW}$.

${ }^{9} \mathrm{Wk} 6$ BCS minus wk 1 BCS.

intake postpartum was higher $(P<0.01)$ for DF versus $\mathrm{LF}$, and calculated postpartum ESC intake was higher $(P<0.006)$ for LF versus DF. Due to lower DMI, postpartum intake of $\mathrm{CP}, \mathrm{OM}, \mathrm{NDF}$, and $\mathrm{ADF}$ were all lower for LF versus DF supplemented cows. Despite differences in EB, treatment averages for postpartum BW were similar, but postpartum BCS was higher $(P$ $<0.04)$ for LF versus DF. Postpartum BW and BCS change were similar among treatments.

\section{Milk and Milk Component Yield and Feed Efficiency}

Milk yield tended $(P=0.07)$ to be higher for WS versus $\mathrm{GH}$, but was not affected by supplement $(P=$ $0.72)$; additionally, yield of $3.5 \%$ FCM were similar among treatments (Table 7). Penner and Oba (2009) observed a 1.4-kg increase in milk yield, and a tendency for improved milk fat yield with sucrose supplementation for cows from 1 to 28 DIM. Other studies have reported trends for increased milk production with sucrose, molasses, or molasses-based liquid feed supplementation (Broderick and Radloff, 2004; Miller et al.,
2005; Miller et al., 2007; Broderick et al., 2008; Firkins et al., 2008). Due to the numerically higher 3.5\% FCM yield and numerically lower DMI, feed efficiency was higher $(P<0.008)$ for LF versus DF.

Starch is fermented in the rumen largely to propionate, which is absorbed through the rumen wall and converted to glucose in the liver, or the starch can pass to the small intestine where it is digested and absorbed as glucose (Firkins et al., 2001). Approximately $75 \%$ of sugar in cane molasses is sucrose; molasses is largely fermented in the rumen and increases molar yields of acetate and butyrate (Broderick and Radloff, 2004; Hall and Weimer, 2007). No treatment effects were noted on the ratio of fat to protein, concentration, or yield of lactose or total solids. A treatment $\times$ week interaction $(P<0.05)$ was observed, as MUN decreased for LF as lactation progressed. Broderick and Radloff, (2004) reported a reduction in MUN when cane molasses was fed at 3 to $9 \%$ of diet DM. A tendency ( $P$ $=0.09)$ for an interaction of forage and supplement indicated higher SCC for cows fed the combination of GH and LF. 
Table 7. Milk and 3.5\% FCM yield, dairy efficiency, milk component concentration, milk component yield, fat to protein ratio, and SCC for multiparous dairy cows fed wheat straw (WS) or grass hay $(\mathrm{GH})$ diets prepartum with either a dry feed (DF) with starch or liquid feed (LF) with sugar supplement both pre- and postpartum

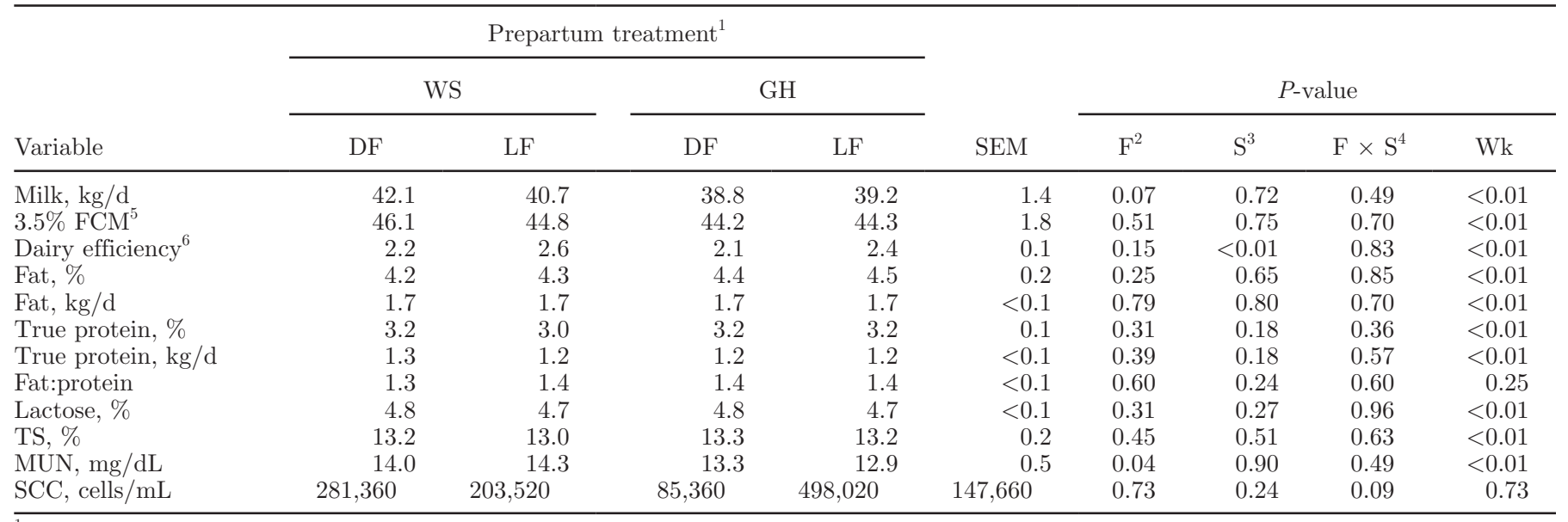

${ }^{1}$ Diets fed from $42 \mathrm{~d}$ prepartum through $56 \mathrm{~d}$ postpartum; wheat straw prepartum + corn-based DF pre- and postpartum (WSDF); wheat straw prepartum + molasses-based LF pre- and postpartum (WSLF); grass hay prepartum + DF pre- and postpartum (GHDF); GH prepartum + LF pre- and postpartum (GHLF); lactation TMR with DF (Starch); lactation TMR with LF (Sugar).

${ }^{2}$ Wheat straw vs. grass hay diets.

${ }^{3}$ Starch vs. sugar supplement.

${ }^{4}$ Interaction of forage type and supplement type.

${ }^{5} 3.5 \% \mathrm{FCM}, \mathrm{kg} / \mathrm{d}=(0.4324 \times \mathrm{kg}$ of milk $)+(16.216 \times \mathrm{kg}$ of milk fat $)$.

${ }^{6}$ Dairy efficiency $=3.5 \% \mathrm{FCM} / \mathrm{DMI}$.

\section{Prepartum Liver Total Lipid, Triglyceride, Glycogen, and Serum NEFA and BHBA}

Biopsies of liver on $\mathrm{d}-14$ prepartum revealed no differences in total lipid or glycogen; however, concentration of liver triglyceride tended $(P=0.06)$ to be greater for LF versus DF (Table 8). The ratio of prepartum liver triglyceride to glycogen was similar among treatments. Concentration of prepartum serum NEFA was greater $(P<0.024$; Figure 1$)$ for LF versus DF, and serum concentration of BHBA on $\mathrm{d}-7$ (Figure $2)$ tended $(P=0.07)$ to be greater for $\mathrm{LF}$ versus $\mathrm{DF}$ (Table 8). Liver composition values are comparable to those reported by Dann et al. (2006) and Janovick and Drackley (2010). Although no prepartum treatment differences were noted among BW or BCS loss, serum NEFA concentrations were greater for LF versus DF, indicating greater body fat mobilization in LF cows and is in agreement with the tendency for lower DMI prepartum.

\section{Postpartum Liver Total Lipid, Triglyceride, Glycogen, and Serum NEFA and BHBA}

Postpartum concentration of total lipids and triglycerides in biopsies of liver tended $(P=0.09)$ to be greater for LF versus DF (Table 8). The concentration of triglycerides in biopsies of liver on $\mathrm{d} 7,14$, and 28 postpartum peaked on d 14 (Figure 3). Postpartum liver glycogen concentration was higher $(P<0.003)$ for cows fed WS versus $\mathrm{GH}$, and tended $(P=0.09)$ to be higher for DF versus LF (Figure 4). The ratio of liver triglyceride to glycogen tended $(P=0.06)$ to be higher for $\mathrm{GH}$ versus WS, but was lower than the ketotic threshold ( $>1.5-2$; Drackley et al., 1992). Postpartum serum NEFA was not different between treatments; postpartum serum NEFA peaked on d 7 and declined thereafter and was higher $(P<0.01)$ for $\mathrm{GH}$ versus WS, but similar among supplements. Serum BHBA, however, was $(P=0.05)$ greater for LF versus DF. Postpartum liver composition and circulating NEFA values are consistent with lower DMI observed for LF. Sucrose supplementation increased both NEFA and BHBA concentration in postpartum cows (Penner and Oba, 2009). Lipid mobilization occurs to support high milk production and is normal in high-producing cows if liver lipid accumulation and circulating NEFA remain below thresholds for hepatic lipidosis and ketosis.

\section{Selective Particle Consumption}

One of the objectives of this study was to determine if LF reduces sorting (selective particle consumption) in a TMR. Given the differences in ingredients (WS vs. GH), it is not surprising that particle size of the TMR were different among treatments (Table 3). In 
Table 8. Prepartum and postpartum concentrations of glycogen, total lipids, and triacylglycerols in biopsies of liver and serum concentration of NEFA and BHBA for multiparous dairy cows fed wheat straw (WS) or grass hay (GH) prepartum with a dry feed (DF) with starch or liquid feed (LF) with sugar supplement both pre- and postpartum

\begin{tabular}{|c|c|c|c|c|c|c|c|c|c|}
\hline \multirow[b]{2}{*}{ Item } & \multicolumn{4}{|c|}{ Prepartum treatment ${ }^{1}$} & \multirow[b]{2}{*}{ SEM } & \multicolumn{4}{|c|}{$P$-value } \\
\hline & $\mathrm{DF}$ & $\mathrm{LF}$ & DF & LF & & $\mathrm{F}^{2}$ & $\mathrm{~S}^{3}$ & $\mathrm{~F} \times \mathrm{S}^{4}$ & Day \\
\hline \multicolumn{10}{|l|}{ Prepartum } \\
\hline Total lipid, ${ }^{5,6} \%$ & 4.4 & 4.4 & 4.5 & 4.5 & 0.2 & 0.73 & 0.91 & 0.98 & - \\
\hline Triacylglycerol, ${ }^{5,6} \%$ & 0.31 & 0.53 & 0.37 & 0.60 & 0.1 & 0.57 & 0.06 & 0.96 & - \\
\hline $\mathrm{NEFA},{ }^{7} \mu \mathrm{Eq} / \mathrm{L}$ & 88.6 & 176.9 & 92.1 & 129.5 & 20.6 & 0.27 & $<0.01$ & 0.20 & $<0.01$ \\
\hline $\mathrm{BHBA},{ }^{8} \mathrm{mmol} / \mathrm{L}$ & 400.0 & 691.7 & 658.3 & 615.4 & 69.7 & 0.18 & 0.07 & 0.02 & - \\
\hline \multicolumn{10}{|l|}{ Postpartum } \\
\hline Total lipid, ${ }^{5,6} \%$ & 8.9 & 9.8 & 9.2 & 11.9 & 1.1 & 0.24 & 0.09 & 0.42 & 0.03 \\
\hline Triacylglycerol,,$^{5,6} \%$ & 4.7 & 5.4 & 4.6 & 7.0 & 0.9 & 0.38 & 0.09 & 0.32 & $<0.01$ \\
\hline Glycogen, ${ }^{5,6} \%$ & 2.9 & 2.3 & 2.0 & 2.0 & 0.2 & $<0.01$ & 0.09 & 0.14 & $<0.01$ \\
\hline Triacylglycerol:glycogen & 2.1 & 3.3 & 3.5 & 4.9 & 0.8 & 0.06 & 0.10 & 0.86 & $<0.01$ \\
\hline
\end{tabular}

${ }^{1}$ Diets fed from $42 \mathrm{~d}$ prepartum through $56 \mathrm{~d}$ postpartum; wheat straw prepartum + corn-based DF pre- and postpartum (WSDF); wheat straw prepartum + molasses-based LF pre- and postpartum (WSLF); grass hay prepartum + DF pre- and postpartum (GHDF); GH prepartum + LF pre- and postpartum (GHLF); lactation TMR with DF (Starch); lactation TMR with LF (Sugar).

${ }^{2}$ Wheat straw vs. grass hay diets.

${ }^{3}$ Starch vs. sugar supplement.

${ }^{4}$ Interaction of forage type and supplement type.

${ }^{5}$ Percent of wet weight.

${ }^{6}$ Liver biopsies on $\mathrm{d}-14$ prepartum and $\mathrm{d}$ 7, 14 and 28 postpartum.

${ }^{7}$ Blood collected $\mathrm{d}-28,-14$, and -7 prepartum and $\mathrm{d} 1,+7,+14$, and +28 postpartum.

${ }^{8}$ Blood collected on $\mathrm{d}-28,-14$, and -7 prepartum and $\mathrm{d}+1,+7,+14$, and +28 postpartum.

general, GH TMR had more particles smaller than 19.0 $\mathrm{mm}$, and the WS diets had more particles 19.0 to 8.0 $\mathrm{mm}$ in length and 8.0 to $1.2 \mathrm{~mm}$ in length. In addition, the adherence properties of LF may have agglomerated some of the fine particles to larger ones, reducing our ability to separate the fine material via PSPS.

During the prepartum period all cows selected against particles smaller than $19.0 \mathrm{~mm}$ in length and selected for particles greater than $1.18 \mathrm{~mm}$ in length (Table 9). Compared with GH, cows fed WS sorted $(P<0.05)$ against particles smaller than $19.0 \mathrm{~mm}$ in length. Additionally, cows fed WS tended $(P=0.06)$ to sort for particles with a length of 8.0 to $1.18 \mathrm{~mm}$ in length. No effect of supplement on selective consumption of particles was observed. Cows were housed in individual tiestalls and had ad libitum access to feed, therefore, differences in sorting between treatments may be more subtle than cows housed and fed as a group. In addition, social dynamics may also influence feeding behavior of group-fed cows.

A greater $(P<0.001)$ mass of particles was retained on the top screen $(>19.0 \mathrm{~mm})$ for LF and tended $(P=$ $0.09)$ to have greater mass in the second screen (particles 19.0-8.0 mm) for LF compared with DF (Table 9). The mass of particles 8.0 to $1.18 \mathrm{~mm}$ in length were similar between treatments, and DF resulted in more $(P$ $<0.001)$ particles larger than $1.18 \mathrm{~mm}$ in length than did LF. The postpartum selective particle consumption also showed that cows did very little measurable particle size sorting during the 24-h period measured (Table 9). Cows fed DF supplement with their lactation TMR tended to consume more particles measuring smaller than 19.0 to $8.0 \mathrm{~mm}$ in length compared with cows fed LF. This finding may be due to smaller particles adhering to the particles larger than $8.0 \mathrm{~mm}$ in length due to the agglomeration properties of the LF, resulting in inflated values for the top 2 screens of the PSPS. Differences in postpartum TMR particle distribution are also likely due to the physical form of the supplement (LF vs. DF). Sorting activity for small TMR particles $(<8 \mathrm{~mm})$ lowers rumen $\mathrm{pH}$ and increases $\mathrm{pH}$ range (Devries et al., 2008). Molasses-based LF can affect particle distribution of corn silage-based lactation diets, reducing small particles $(<8 \mathrm{~mm})$ on the bottom pan of the PSPS, and increasing material $(>8$ to $<19$ $\mathrm{mm}$ ) on the middle screen of the PSPS. However, the extent of molasses-based liquid feed's effect on particle distribution is affected by forage type, processing, and overall diet particle distribution (Oelker et al., 2009). Consequently, reducing the proportion of fine particles 


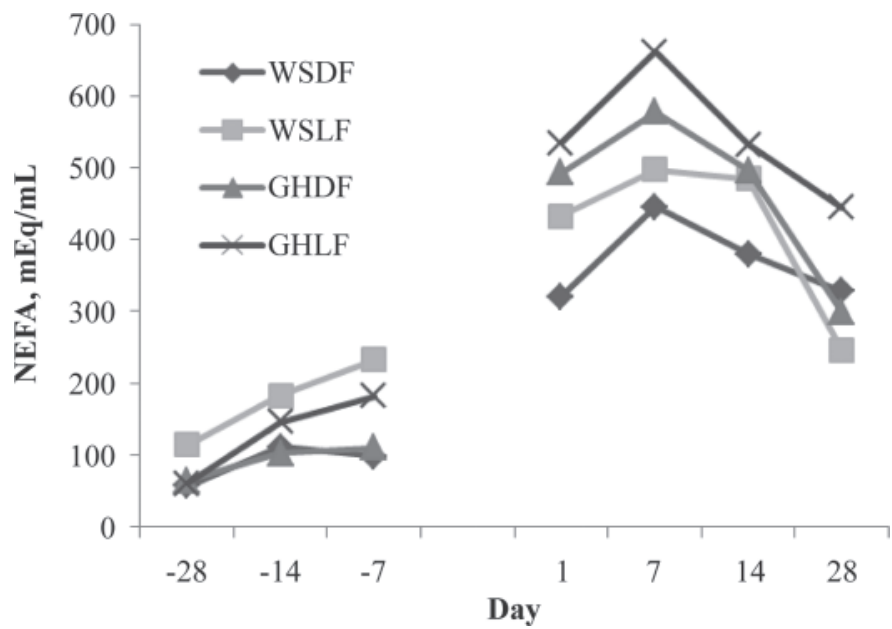

Figure 1. Pre- and postpartum serum NEFA for multiparous dairy cows fed diets from $42 \mathrm{~d}$ prepartum through $56 \mathrm{~d}$ postpartum; wheat straw prepartum + corn-based dry feed (DF) pre- and postpartum (WSDF); wheat straw prepartum + molasses-based liquid feed (LF) pre- and postpartum (WSLF); grass hay prepartum + DF pre- and postpartum (GHDF); GH prepartum + LF pre- and postpartum (GHLF); lactation TMR with DF (Starch); lactation TMR with LF (Sugar). Prepartum: forage, $P=0.27$; supplement, $P<0.002$; day, $P$ $<0.001$; day $\times$ forage, $P=0.99$; day $\times$ supplement, $P=0.09$; day $\times$ forage $\times$ supplement, $P=0.77$. Largest SEM $=20.1 \mathrm{mEq} / \mathrm{mL}$. Postpartum: forage, $P<0.01$; supplement, $P=0.16$; day $=P<0.001$; day $\times$ forage, $P=0.80$; day $\times$ supplement, $P=0.94$; day $\times$ forage $\times$ supplement, $P=0.20$. Largest $\mathrm{SEM}=44.5 \mathrm{mEq} / \mathrm{mL}$. For clarity, $\mathrm{SE}$ bars have been omitted.

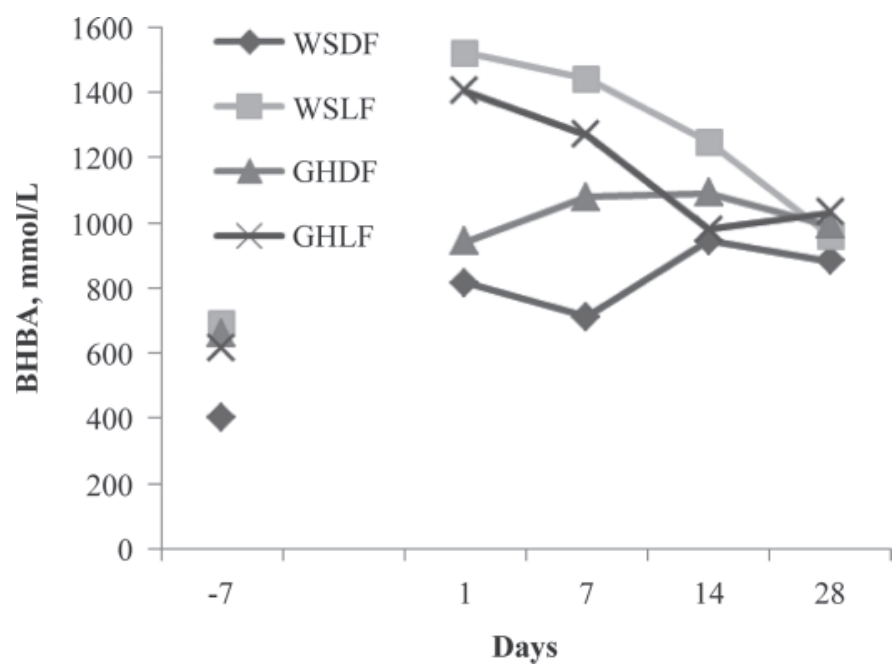

Figure 2. Pre- and postpartum serum BHBA for multiparous dairy cows fed diets from $42 \mathrm{~d}$ prepartum through $56 \mathrm{~d}$ postpartum; wheat straw prepartum + corn-based dry feed (DF) pre- and postpartum (WSDF); wheat straw prepartum + molasses-based liquid feed (LF) pre- and postpartum (WSLF); grass hay prepartum + DF pre- and postpartum (GHDF); GH prepartum + LF pre- and postpartum (GHLF); lactation TMR with DF (Starch); lactation TMR with LF (Sugar). Prepartum: forage, $P=0.18$; supplement, $P=0.07$; forage $\times$ supplement, $P=0.02$. Largest SEM $=69.7 \mathrm{mmol} / \mathrm{mL}$. Postpartum: forage, $P=0.82$; supplement, $P=0.05$; day, $P=0.45$; day $\times$ forage $P=0.91$; day $\times$ supplement, $P=0.13$; day $\times$ forage $\times$ supplement, $P=0.79$. Largest SEM $=161.3 \mathrm{mmol} / \mathrm{mL}$. For clarity, SE bars have been omitted.

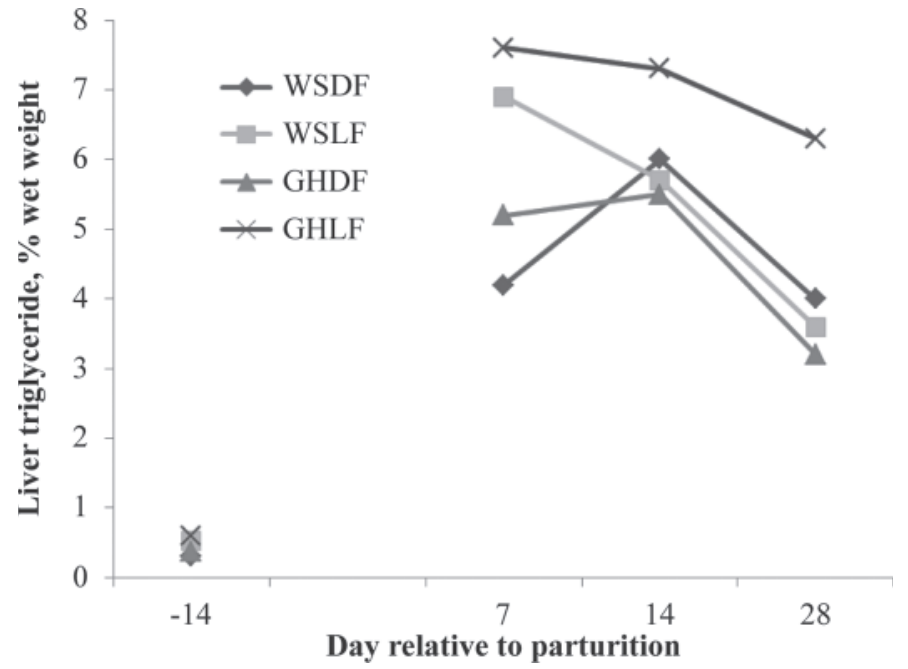

Figure 3. Pre- and postpartum liver triglyceride concentration for multiparous dairy cows fed diets from $42 \mathrm{~d}$ prepartum through $56 \mathrm{~d}$ postpartum; wheat straw prepartum + corn-based dry feed (DF) preand postpartum (WSDF); wheat straw prepartum + molasses-based liquid feed (LF) pre- and postpartum (WSLF); grass hay prepartum + DF pre- and postpartum (GHDF); GH prepartum + LF pre- and postpartum (GHLF); lactation TMR with DF (Starch); lactation TMR with LF (Sugar). Prepartum: forage, $P=0.57$; supplement, $P=0.06$; forage $\times$ supplement, $P=0.96$. Largest SEM $=0.12 \%$ tissue wet weight. Postpartum: forage, $P=0.38$; supplement, $P=0.09$; day, $P$ $<0.0001$; day $\times$ forage, $P=0.87$; day $\times$ supplement, $P=0.09$; day $\times$ forage $\times$ supplement, $P=0.10$. Largest SEM $=0.99 \%$ tissue wet weight. For clarity, SE bars have been omitted.

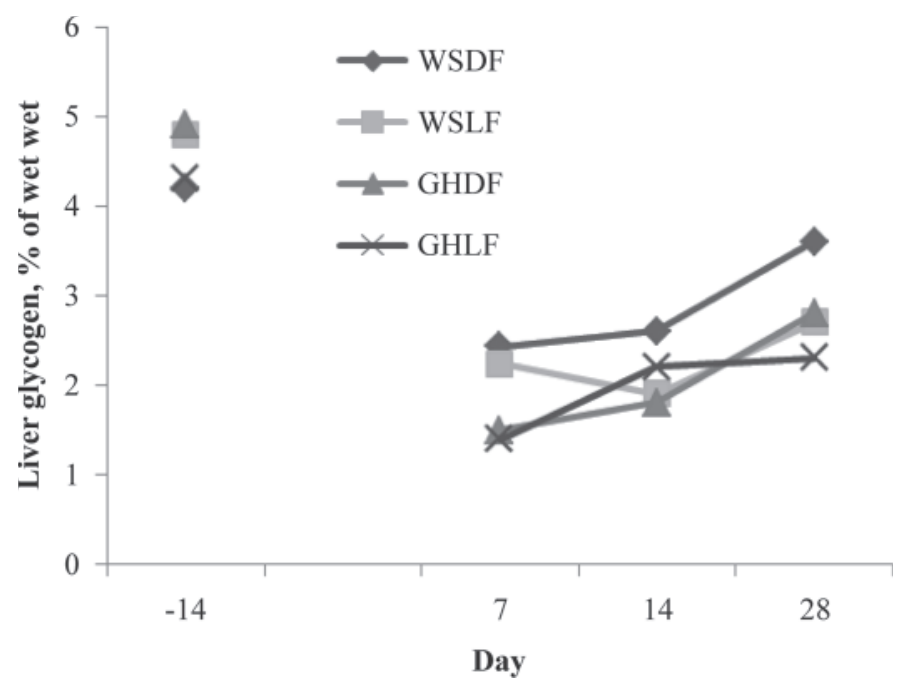

Figure 4. Pre- and postpartum liver glycogen concentration for multiparous dairy cows fed diets from 42 d prepartum until calving; wheat straw prepartum + corn (WSDF); wheat straw prepartum + molasses-based liquid feed (LF; WSLF); grass hay prepartum + corn (GHDF); GH prepartum + LF (GHLF) and prepartum sugar and starch supplementation continued through $56 \mathrm{~d}$ postpartum. Prepartum: forage, $P=0.84$; supplement, $P=0.97$; forage $\times$ supplement, $P=0.24$. Largest SEM $=0.5 \%$ tissue wet weight. Postpartum: forage, $P<0.003$; supplement, $P=0.09$; day, $P<0.001$; day $\times$ forage, $P=0.37$; day $\times$ supplement, $P=0.30$; day $\times$ forage $\times$ supplement, $P=0.48$. Largest SEM $=0.2 \%$ tissue wet weight. For clarity, SE bars have been omitted. 
Table 9. Particle size, DM, and calculated selective particle consumption in prepartum diets using a Penn State particle size separator box for multiparous dairy cows fed wheat straw (WS) or grass hay $(\mathrm{GH})$ diets prepartum with either a starch or sugar supplement both pre- and postpartum

\begin{tabular}{|c|c|c|c|c|c|c|c|c|}
\hline \multirow{3}{*}{$\begin{array}{l}\text { Item } \\
{[100 \times(\text { intake/predicted }} \\
\text { intake })], \text { as fed retained }\end{array}$} & \multicolumn{4}{|c|}{ Prepartum treatment $^{1}$} & \multirow[b]{3}{*}{ SEM } & \multirow{2}{*}{\multicolumn{3}{|c|}{$P$-value }} \\
\hline & \multicolumn{2}{|c|}{ WS } & \multicolumn{2}{|c|}{ GH } & & & & \\
\hline & $\mathrm{DF}$ & $\mathrm{LF}$ & $\mathrm{DF}$ & $\mathrm{LF}$ & & $\mathrm{F}^{2}$ & $S^{3}$ & $\mathrm{~F} \times \mathrm{S}^{4}$ \\
\hline \multicolumn{9}{|l|}{ Prepartum } \\
\hline $19.0 \mathrm{~mm}$ & 95.1 & 89.8 & 98.5 & 96.4 & 2.4 & 0.03 & 0.11 & 0.48 \\
\hline $8.0 \mathrm{~mm}$ & 97.7 & 97.7 & 98.1 & 97.3 & 0.9 & 0.98 & 0.68 & 0.60 \\
\hline \multicolumn{9}{|l|}{ Postpartum } \\
\hline$>19.0 \mathrm{~mm}$ & 95.2 & 95.2 & 98.7 & 92.1 & 2.8 & 0.95 & 0.21 & 0.21 \\
\hline 19.0 to $8.0 \mathrm{~mm}$ & 100.0 & 99.2 & 99.6 & 97.0 & 1.0 & 0.13 & 0.06 & 0.36 \\
\hline 8.0 to $1.18 \mathrm{~mm}$ & 99.1 & 99.6 & 99.2 & 101.2 & 0.8 & 0.32 & 0.16 & 0.38 \\
\hline$<1.18 \mathrm{~mm}$ & 102.3 & 103.4 & 103.0 & 104.6 & 1.1 & 0.37 & 0.22 & 0.83 \\
\hline
\end{tabular}

${ }^{1}$ Diets fed from $42 \mathrm{~d}$ prepartum through $56 \mathrm{~d}$ postpartum; wheat straw prepartum + corn-based dry feed (DF) pre- and postpartum (WSDF); wheat straw prepartum + molasses-based liquid feed (LF) pre- and postpartum (WSLF); grass hay prepartum + dry feed pre- and postpartum (GHDF); GH prepartum + liquid feed pre- and postpartum (GHLF); lactation TMR with dry feed (Starch); lactation TMR with liquid feed (Sugar).

${ }^{2}$ Wheat straw vs. grass hay diets.

${ }^{3}$ Starch vs. sugar supplement.

${ }^{4}$ Interaction of forage type and supplement type.

in the TMR has the additional benefit of providing cows less opportunity to sort for fine particles, reducing the risk of suboptimal rumen $\mathrm{pH}$ and the resulting negative effects on feed utilization. In a field survey, Overton et al. (2008) demonstrated that the amount of particles 19.0 to $8.0 \mathrm{~mm}$ and larger than $8.0 \mathrm{~mm}$ in length has a significant relationship to herd milk fat percent. This research demonstrates that a molassesbased liquid supplement reduces the amount of fines in the TMR and agglomerates small particles to larger ones, increasing the amount of material larger than 8.0 $\mathrm{mm}$ in the TMR particle distribution.

\section{CONCLUSIONS}

Prepartum forage and supplement had only modest effects on prepartum intake, diet digestibility, and selective particle consumption. A single-stage dry cow TMR containing 30\% DM of chopped WS or GH maintained DMI and EB through calving. Prepartum energy intake tended to be closer to requirements for maintenance and pregnancy for cows fed WS versus GH. Prepartum LF decreased DM digestibility and increased liver triglycerides, circulating NEFA, and tended to increase BHBA. Liquid feeds decreased postpartum DMI and EB but not milk or $3.5 \%$ FCM yield, resulting in increased feed efficiency. Prepartum forage did not affect postpartum DMI, although milk yield tended to be higher for WS versus GH and may be linked to higher NDFd of WS and GH potassium concentration interfering with calcium homeostasis, al- though blood calcium was not measured in this study. Additionally, compared with GH, WS resulted in lower postpartum NEFA, higher liver glycogen, and tended to have a lower triglyceride to glycogen ratio. Liquid feeds reduced the amount of fine particles in the lactation diet but had minimal effects on postpartum selective particle consumption.

\section{ACKNOWLEDGMENTS}

This study was supported by federal and state funds appropriated to the Minnesota Agricultural Experiment Station (St. Paul) and Quality Liquid Feeds Inc. (Dodgeville, WI).

\section{REFERENCES}

Agenäs, S., E. Burstedt, and K. Holtenius. 2003. Effects of feeding intensity during the dry period. 1 . Feed intake, body weight, and milk production. J. Dairy Sci. 86:870-882.

AOAC International. 2000. Official Methods of Analysis. 17th ed. AOAC International, Gaithersburg, MD.

Bach Knudsen, K. E. 1997. Carbohydrate and lignin contents of plant and materials used in animal feeding. J. Anim. Feed Sci. Tech. 67:319-338.

Beever, D. E. 2006. The impact of controlled nutrition during the dry period on dairy cow health, fertility, and performance. Anim. Reprod. Sci. 96:212-226.

Block, E., L. H. Kilmer, and L. D. Muller. 1981. Acid insoluble ash as a marker of digestibility for sheep fed corn plants or hay for lactating dairy cattle fed hay ad libitum. J. Anim. Sci. 52:1164-1169.

Broderick, G. A., N. D. Luchini, S. M. Reynal, G. A. Varga, and V. A. Ishler. 2008. Effect on production of replacing dietary starch with sucrose in lactating dairy cows. J. Dairy Sci. 91:4801-4810.

Broderick, G. A., and W. J. Radloff. 2004. Effect of molasses supplementation on the production of lactating dairy cows fed diets based on alfalfa and corn silage. J. Dairy Sci. 87:2997-3009. 
Colucci, P. E., L. E. Chase, and P. J. Van Soest. 1982. Feed intake, apparent diet digestibility, and rate of particulate passage in dairy cattle. J. Dairy Sci. 65:1445-1456.

Dairy One. 1999. New net energy equations. Accessed Feb. 12, 2004. www.dairyone.com/Forage/newsletters/199903.pdf.

Dann, H. M., N. B. Litherland, J. P. Underwood, M. Bionaz, A. D'Angelo, J. W. McFadden, and J. K. Drackley. 2006. Diets during far-off and close-up dry periods affect periparturient metabolism and lactation in multiparous cows. J. Dairy Sci. 89:3563-3577.

Devries, T. J., F. Dohme, and K. A. Beauchemin. 2008. Repeated ruminal acidosis challenges in lactating dairy cows at high and low risk for developing acidosis: Feed sorting. J. Dairy Sci. 91:3958 3967.

Drackley, J. K., M. J. Richard, D. C. Beitz, and J. W. Young. 1992. Metabolic changes in dairy cows with ketonemia in response to feed restriction and dietary 1,3-butanediol. J. Dairy Sci. 75:16221634.

Ferguson, J. D., D. T. Galligan, and N. Thomsen. 1994. Principal descriptors of body condition score in Holstein cows. J. Dairy Sci. 77:2695-2703.

Firkins, J. L., M. L. Eastridge, N. R. St-Pierre, and S. M. Noftsger 2001. Effects of grain variability and processing on starch utilization by lactating dairy cattle. J. Anim. Sci. 79(E Suppl.):E218E238.

Firkins, J. L., B. S. Oldick, J. Pantoja, C. Reveneau, L. E. Gilligan, and L. Carver. 2008. Efficacy of liquid feeds varying in concentration and composition of fat, nonprotein nitrogen, and nonfiber carbohydrates for lactating cows. J. Dairy Sci. 91:1969-1984.

Fletcher, M. J. 1968. A colorimetric method for estimating serum triglycerides. Clin. Chim. Acta 22:393-397.

Foster, L. B., and R. T. Dunn. 1973. Stable reagents for determination of serum triglycerides by a colorimetric Hantzsch condensation method. Clin. Chem. 19:338-340.

Grummer, R. R., D. G. Mashek, and A. Hayirli. 2004. Dry matter intake and energy balance in the transition period. Vet. Clin. North Am. Food Anim. Pract. 20:447-470.

Hall, M. B., and P. J. Weimer. 2007. Sucrose concentration alters fermentation kinetics, products, and carbon fates during in vitro fermentation with mixed ruminal microbes. J. Anim. Sci. $85: 1467-1478$.

Hara, A., and N. S. Radin. 1978. Lipid extraction of tissues with a low-toxicity solvent. Anal. Biochem. 90:420-426.

Holcomb, C. S., H. H. Van Horn, H. H. Head, M. B. Hall, and C. J. Wilcox. 2001. Effects of prepartum dry matter intake and forage percentage on postpartum performance of lactating dairy cows. J. Dairy Sci. 84:2051-2058.

Hosseinkhani, A., T. J. DeVries, K. L. Proudfoot, R. Valizadeh, D M. Veira, and M. A. G. von Keyserlingk. 2008. The effects of feed bunk competition on the feed sorting behavior of close-up dry cows. J. Dairy Sci. 91:1115-1121.

Hughes, J. P. 1962. A simplified instrument for obtaining liver biopsies in cattle. Am. J. Vet. Res. 23:1111-1113.

Janovick, N. A., Y. R. Boisclair, and J. K. Drackley. 2011. Prepartum dietary energy intake affects metabolism and health during the periparturient period in primiparous and multiparous Holstein cows. J. Dairy Sci. 94:1385-1400.

Janovick, N. A., and J. K. Drackley. 2010. Prepartum dietary management of energy intake affects postpartum intake and lactation performance by primiparous and multiparous Holstein cows. J. Dairy Sci. 93:3086-3102.
Leonardi, C., F. Giannico, and L. E. Armentano. 2005. Effect of water addition on selective consumption (sorting) of dry diets by dairy cattle. J. Dairy Sci. 88:1043-1049.

Litherland, N. B., M. L. Raeth-Knight, and J. G. Linn. 2010. Diets containing thirty percent wheat straw or orchard grass hay fed at either ad libitum or restricted intake prepartum have modest effects on postpartum performance. J. Dairy Sci. 93(E-Suppl. 1):838. (Abstr.)

Littell, R. C., G. A. Milliken, W. W. Stroup, and R. D. Wolfinger. 1996. SAS System of Mixed Models. SAS Institute, Cary, NC.

Lo, S., J. C. Russell, and A. W. Taylor. 1970. Determination of glycogen in small tissue samples. J. Appl. Physiol. 28:234-236.

Mashek, D. G., and D. K. Beede. 2000. Peripartum responses of dairy cows to partial substitution of corn silage with corn grain in diets fed during the late dry period. J. Dairy Sci. 83:2310-2318.

Miller, W. F., B. J. Johnson, E. C. Titgemeyer, J. F. Smith, J. E. Shirley, and T. G Nagaraja. 2007. Effect of cane molasses on ruminal absorptive capacity of dairy cows during the periparturient period. Page 88 in Proc. Midwest Sect. Am. Dairy Sci. Assoc. http://adsa. asas.org/midwest/2007/2007Abstracts.pdf.

Miller, W. F., J. E. Shirley, J. M. Rottinghaus, E. C. Titgemeyer, and D. E. Johnson. 2005. Effect of dietary inclusion of cane molasses in dry cow diets on prepartum and postpartum performance. J. Dairy Sci. 88(Suppl. 1):221. (Abstr.)

Nombekela, S. W., and M. R. Murphy. 1995. Sucrose supplementation and feed intake of dairy cows in early lactation. J. Dairy Sci. 78:880-885.

NRC. 2001. Nutrient Requirements of Dairy Cattle. 7th rev. ed. Natl. Acad. Sci., Washington DC.

Oelker, E. R., C. Reveneau, and J. L. Firkins. 2009. Interaction of molasses and monensin in alfalfa hay-or corn silage-based diets on rumen fermentation, total tract digestibility, and milk production by Holstein cows. J. Dairy Sci. 92:270-285.

Overton, T. R., D. V. Nydam, D. E. Bauman, T. C. Jenkins, and G. D. Mechor. 2008. Field study to investigate the risk factors for milk fat depression (MFD) in dairy herds feeding Rumensin. Pages 113124 in Proc. Cornell Nutr. Conf. Cornell University, Ithaca, NY.

Penner, G. B., and M. Oba. 2009. Increasing dietary sugar concentration may improve dry matter intake, ruminal fermentation, and productivity of dairy cows in the postpartum phase of the transition period. J. Dairy Sci. 92:3341-3353.

Rabelo, E., R. L. Rezende, S. J. Bertics, and R. R. Grummer. 2003. Effects of transition cow diets varying in dietary energy density on lactation performance and ruminal parameters of dairy cows. J. Dairy Sci. 86:916-925.

Rérat, M., A. Philipp, H. D. Hess, and A. Liesegang. 2009. Effect of different potassium levels in hay on acid-base status and mineral balance in periparturient dairy cows. J. Dairy Sci. 92:6123-6133.

Van Soest, P. J., J. B. Robertson, and B. A. Lewis. 1991. Methods for dietary fiber, neutral detergent fiber, and nonstarch polysaccharides in relation to animal nutrition. J. Dairy Sci. 74:3583-3597.

Vandehaar, M. J., G. Yousif, B. K. Sharma, T. H. Herdt, R. S. Emery, M. S. Allen, and J. S. Liesman. 1999. Effect of energy and protein density of prepartum diets on fat and protein metabolism of dairy cattle in the periparturient period. J. Dairy Sci. 82:1282-1295.

Veenhuizen, J. J., J. K. Drackley, M. J. Richards, T. P. Sanderson, L. D. Miller, and J. W. Young. 1991. Metabolic changes in blood and liver during development and early treatment of experimental fatty liver and ketosis in cows. J. Dairy Sci. 74:4238-4253. 